\title{
An overview of treatment response rates to various anti-viral drugs in Pakistani Hepatitis $B$ Virus infected patients
}

\author{
Liaqat Ali, Muhammad Idrees*, Muhammad Ali, Irshad-ur Rehman, Abrar Hussain, Samia Afzal, Sadia Butt, \\ Sana Saleem, Saira Munir, Sadaf Badar
}

\begin{abstract}
Hepatitis B virus (HBV) is one of the leading health problem with up to 350 million affected people worldwide including 4.5 million only in Pakistan. It has mortality rate of 0.5 to 1.2 million per year worldwide. Pakistan lies in the endemic region with 3-5\% HBV carrier rate in the country. The present article reviews the literature on the treatment response of HBV prevalent in Pakistani population. The average treatment response of Lamivudine and interferon- $\alpha$ is $25.81 \%$ and $47.95 \%$, respectively. Peg-Interferon was shown to be not effective against the HBV/HCV (hepatitis C virus)/HDV (hepatitis Delta virus) co-infection. The present study reveals that interferon- $\alpha$ is the most effective therapy available for HBV infection prevalent in Pakistani population. Genotype C \& D are the most common HBV genotypes in Pakistan and are associated with increased severity and less response to interferon therapy. This poses a great challenge for physicians and researchers and further studies are needed to describe the outcome of the current therapies recommended against HBV infection in Pakistani population.
\end{abstract}

\section{Introduction}

Hepatitis B virus (HBV) is a crucial health problem with up to 350 million affected people worldwide [1]. HBV is a member of the Hepadnaviridae family with 3.2 kilobase pair DNA genome which is partially doublestranded [2,3]. Pre-s domain surface protein is mediates its attachment to the cell membrane [4].

Several previous studies on the association of the HBV genotypes with disease progression reported that genotypes $\mathrm{B}$ and $\mathrm{C}$ are correlated with severity of liver dysfunction while high viral loads were observed in patients infected with genotype C [5,6], A, and D [7] in some studies but not in others $[8,9]$. According to WHO, Pakistan has low HBV infection rates of $3 \%$, while studies from Pakistan are more focused towards the HBV prevalence rate $[10,11]$, epidemiological issues [12], genotyping and its core antigen genetic variability [13].

Approved drugs advised for the treatment of HBV include interferon- $\alpha$, PEG-interferon and antiviral drugs

\footnotetext{
* Correspondence: liaqatbiotech@yahoo.com; idreeskhan96@yahoo.com Division of Molecular Virology, National Centre of Excellence in Molecular Biology, University of the Punjab, 87 - West Canal Bank Road, Thoker Niaz Baig, Lahore 53700, Pakistan
}

(c) 2011 Ali et al; licensee BioMed Central Ltd. This is an Open Access article distributed under the terms of the Creative Commons Attribution License (http://creativecommons.org/licenses/by/2.0), which permits unrestricted use, distribution, and reproduction in any medium, provided the original work is properly cited.

like lamivuaine, adefovir, dipivoxil, entecavir and telbivudine. Hepatitis $B$ antibodies and the HBV vaccine within 12 hours of birth help to prevent the infection [14]. In Pakistan, there are estimated 4.5 million carriers of HBV with a carrier rate of 3-5\%. However, studies are limited describing HBV treatment response in Pakistani population. The present article reviews all the available literature on the treatment response to the available therapies against HBV prevalent in Pakistani population (Table 1).

\section{Anti viral efficacy of lamivudine}

A nucleoside analogue called lamivudine, has anti-HBV and anti-HIV properties, was approved by the US-FDA in 1998 for the treatment of HBV infections. It is administered orally with concentration of $100 \mathrm{mg} /$ day [15]. Use of lamivudine is reported to decrease the circulating DNA levels of HBV $[16,17]$ while long term decrease has been achieved after one month's therapy [18]. In Pakistani population, the rate of seroconversion against lamivudine was observed to be $16 \%$ in HBV/HDV(Hepatitis delta Virus) co-infected patients when administered for 36 months [19], 23 to $38 \%$ in HBV infected patients when administered for 12 months and 36 months, 
Table 1 An overview of treatment outcome in Pakistani HBV treated patients

\begin{tabular}{|c|c|c|c|c|c|c|}
\hline Author & Region & $\begin{array}{l}\text { Patients } \\
\text { (n) }\end{array}$ & Etiology & Treatment & Duration (weeks) & Results \\
\hline $\begin{array}{l}\text { Qureshi } \\
\text { et al: [19] }\end{array}$ & Karachi & 69 & $\begin{array}{l}\mathrm{HBeAg}, \mathrm{HBV} \text { DNA } \\
\text { positive patients }\end{array}$ & $\begin{array}{l}100 \text { mg of } \\
\text { Lamivudine orally } \\
\text { before breakfast till } \\
\text { seroconversion }\end{array}$ & 36 months & $\begin{array}{l}38 \% \text { cases were observed to sero- } \\
\text { converted. }\end{array}$ \\
\hline $\begin{array}{l}\text { Qureshi } \\
\text { et al: [19] }\end{array}$ & Karachi & 55 & $\begin{array}{l}\text { HBV DNA positive } \\
\text { (wild type) with } \\
\text { delta positive }\end{array}$ & $\begin{array}{l}100 \text { mg of } \\
\text { Lamivudine orally } \\
\text { before breakfast till } \\
\text { seroconversion }\end{array}$ & 36 months & $\begin{array}{l}16.4 \% \text { cases in group } 2 \text { sero-converted } \\
\text { (Wild type of HBV/HDV co-infected cases } \\
\text { have a } 16 \% \text { chance of seroconversion) }\end{array}$ \\
\hline $\begin{array}{l}\text { Naeem } \\
\text { et al: [31] }\end{array}$ & Rawalpindi & 50 & $\begin{array}{l}\text { Chronic viral } \\
\text { hepatitis B (HBsAg } \\
\text { and HBV DNA } \\
\text { positive) }\end{array}$ & $\begin{array}{l}5 \text { mega units of } \\
\text { recombinant } \\
\text { interferon alfa- } 2 b \\
\text { subcutaneously once } \\
\text { daily }\end{array}$ & 4-months & $\begin{array}{l}\text { HBV DNA was found negative in } 44.0 \% \text { (22) } \\
\text { patients while treatment was ceased in } \\
\text { three patients due to severe depression. }\end{array}$ \\
\hline $\begin{array}{l}\text { Zuberi } \\
\text { et al: [21] }\end{array}$ & Karachi & 246 & $\begin{array}{l}\text { co/super-infection } \\
\text { of Hepatitis } C \text { and } \\
D \text { among patients } \\
\text { of HBV }\end{array}$ & $\begin{array}{l}\text { pegylated interferon- } \\
\text { a 2a } 180 \text { mcg sc } \\
\text { weekly }\end{array}$ & 48 weeks & HBV was not cleared in any case \\
\hline $\begin{array}{l}\text { Zuberi } \\
\text { et al: [32] }\end{array}$ & Karachi & 52 & $\begin{array}{l}\text { patients of } \\
\text { hepatitis B with } \\
\text { hepatitis D }\end{array}$ & $\begin{array}{l}\text { Interferon - a } 10.0 \\
\text { MIU sc t.i.w. }\end{array}$ & 48 weeks & $\begin{array}{l}\text { 51.9\% patients had suppressed }(<400 \\
\text { copies/ml) HBV DNA levels }\end{array}$ \\
\hline $\begin{array}{l}\text { Khokhar } \\
\text { et al. [21] }\end{array}$ & Islamabad & 105 & $\begin{array}{l}\text { positive HBsAg } \\
\text { and elevated ALT }\end{array}$ & $\begin{array}{l}\text { lamivudine } 100 \mathrm{mg} \\
\text { once a day for } 12 \\
\text { months }\end{array}$ & $\begin{array}{l}12 \text { months and were } \\
\text { followed every } 2-3 \\
\text { months with ALT, } \\
\text { HBeAg and HBV DNA }\end{array}$ & $\begin{array}{l}\text { HBeAg positive and } \mathrm{HBeAg} \text { negative } \\
\text { patients were found with } 23.6 \% \text { and } 80.0 \% \\
\text { treatment response rate respectively (All } \\
\text { the patients were } \mathrm{HBsAg} \text { positive) }\end{array}$ \\
\hline
\end{tabular}

respectively (Table 1) [20,21]. A much higher HBV response rate is being observed in Pakistani population than reported earlier [22]. These studies show that lamivudine monotherapy is a better option for treatment of HBV infection but this therapy require longer durations (up to 36 months) and develop increased resistance (up to $20 \%$ after one year and $70 \%$ after 5 years of therapy) $[23,24]$, which makes it undesirable for the patients.

Nucleotide and nucleoside analogues are shown to be associated with minimum side effects as compared to the standard INF and PEG-INF therapies. These include short term adversed effects like myopathy, neuropathy and lactic acidosis [25]. These include side effects like abdominal pain, headache, cough, nasopharyngitis, pyrexia, diarrhea and fatigue [26].

\section{Anti viral efficacy of Peg-Interferon}

Interferon is supplemented with polyethylene glycol (PEG) which prolongs its half-life resulting in sustained antiviral response rates. Two types of PEG-IFN have been studied for HBV therapy, PEG-IFN $\alpha$-2a having a large $40 \mathrm{kDa}$ PEG branched and PEG-IFN $\alpha$-2b with a $12 \mathrm{kDa}$ PEG molecule [27]. Buster and Janssen [22] reported HBV treatment response of $19-35 \%$ by administration of peg-IFN. However, administration of pegylated interferon- $\alpha 2 \mathrm{a}$ for 4 months failed to treat the HBV, HDV and HCV co-infection in Pakistani population [20] and is associated with adverse effects like depression, flu-like symptoms, neuropsychiatric disorders and suppression of bone marrow [28].
This shows that peg-interferon is not effective against $\mathrm{HBV}$ when administered in $\mathrm{HBV} / \mathrm{HDV} / \mathrm{HCV}$ co-infected patients. However, there is no study describing the use of peg-interferon against $\mathrm{HBV}$ infected Pakistani population.

\section{Anti viral efficacy of Interferon- $\alpha$ (IFN- $\alpha$ )}

IFN- $\alpha$ was approved in 1992 after being extensively studied. It is reported to increase hepatitis B surface antigen (HBsAg) expression by hepatocytes and inhibit packaging of pre-genomic viral RNA into the core particles [29]. Currently, many different types of interferon are available but available data is limited to support advantage of one therapy to be more effective than the others. However, the response rate of $30-40 \%$ was reported by the administration of IFN- $\alpha$ for 6-12 months as compared to $10-20 \%$ in controls. Patients with lower ALT and/or higher HBV viral loads and immunosuppressed patients are the risk factors that result in decreased response to IFN treatment. Hepatitic flares are shown to predict sustained virological response during interferon treatment [30]. Naeem and coworkers [31] reported that administration of 5MIU of recombinant IFN- $\alpha-2 b$ for four months lead to response in $44 \%$ of Pakistani patients. On the other hand, Zuberi and colleagues [32] described an increased treatment response of $51.9 \%$ after administration of $10.0 \mathrm{MIU}$ of IFN- $\alpha$ in HBV infected patients for the same period of 16 weeks. IFN- $\alpha$ is also shown to be associated with the development of side effects like insomnia, fatigue, 
alopecia and anorexia [33,34]. However, further studies on the treatment response and follow up of patients are needed to understand the effectiveness of INF- $\alpha$ against HBV infection in Pakistani population.

\section{HBV genetic heterogeneity and Antiviral Therapy}

HBV has been classified into 9 genotypes (A-I) based on $8 \%$ or more inter-group divergence in full length genomic sequence [35-38] and its antiviral treatment response rate is highly affected by genetic variability as well as by various host and viral factors.

The most recent study conducted throughout Pakistan has reported that HBV genotype $\mathrm{C}$ is the most prevalent genotype in Pakistan with $26.7 \%$ prevalence, followed by genotype B (18\%), A (14.3\%), D (13\%), mixed genotypes (14.6\%) and $10.3 \%$ were found untypable [38]. While genotypes $\mathrm{E}(0.6 \%)$ and $\mathrm{F}(1.3 \%)$ have been reported recently in Pakistan. A very high prevalence of HBV genotype D (60-100\%) were also reported from different regions of Pakistan [39-44,13]. It is well understood that both genotype $\mathrm{C} \& \mathrm{D}$ are less responsive to interferon therapy and associated with more severe disease than genotype A and B [45,46]. Moreover, these genotypes are reported to be less frequently related to $\mathrm{HBeAg}$ clearance rates than genotypes $\mathrm{A}$ and $\mathrm{B}$ when treated with pegylated interferon [47]. Another study revealed that antiviral response rate against IFN-alpha was higher in genotype $\mathrm{F}$ as compared to genotypes $\mathrm{E}$ and $\mathrm{G}$ [48].

The high prevalence of HBV genotype $\mathrm{D}$ and $\mathrm{C}$ in Pakistani population and its association with increased severity of the disease and resistance to the present therapies demands more consistent preventive measures like mass vaccination and awareness programs at national level.

\section{Conclusion}

This review explains that interferon- $\alpha$ is the most effective available drug against the HBV prevalent in Pakistan with up to $47.95 \%$ treatment response rate. Moreover, treatment of the resistant but most prevalent HBV genotypes $\mathrm{C}$ and $\mathrm{D}$ is a challenge for clinicians and scientists in our region. However, further studies are needed to fully describe the treatment response and the risk factors of the currently recommended therapies against HBV infection especially combination therapy of interferon and lamivudine in Pakistani isolates. These future prospects will enable the virologists to focus drug designing in this part of the world.

\section{Authors' contributions}

$L A$ and $M A$ reviewed the literature, and wrote the manuscript. MI reviewed the manuscript. IR, AH, SA, SB, SS, SM and SB helped LA \& MA in literature review. All the authors read and approved the final manuscript.

\section{Competing interests}

The authors declare that they have no competing interests.

Received: 5 December 2010 Accepted: 15 January 2011

Published: 15 January 2011

References

1. Awan Z, Idrees M, Rafique S, Rehman I, Akbar H, But S, et al: Hepatitis B virus YMDD-motif mutations with emergence of lamivudine-resistant mutants: a threat to recovery. Gastroenterology and Hepatology From Bed to Bench 2010, 3:108-114.

2. Lee W: Hepatitis B virus infection. N Engl J Med 1997, 337:1733-1745.

3. Ganem D, Schneiden RJ, et al: Hepadnaviridae: the viruses and their replication. In Fields Virology. Edited by: Knipe DM, Howely PM, Griffin DE. Philadelphia: Lippincott-Raven; 2001:292-2969.

4. Klingmuller $\mathrm{U}$, Schallen $\mathrm{H}$ : Hepadnavirus infection requires interaction between the viral pre-s domain and a specific hepatocellular receptor. J Virol 1993, 67:7414-7422.

5. Sugauchi F, Chutaputti A, Orito E, Kato H, Suzuki S, Ueda R, Mizokami M: Hepatitis $B$ virus genotypes and clinical manifestation among hepatitis $B$ carriers in Thailand. J Gastroenterol Hepatol 2002, 17:671-676.

6. Ishikawa K, Koyama T, Masuda T: Prevalence of HBV genotypes in asymptomatic carrier residents and their clinical characteristics during long-term follow-up: the relevance to changes in the $\mathrm{HBeAg} / \mathrm{anti-HBe}$ system. Hepatol Res 2002, 24:1

7. Westland C, Delaney W, Yang H, Gibbs C, Miller M, Wulfsohn MJ: Hepatitis $B$ virus genotypes and virologic response in 694 patients in phase III studies of adefovir dipivoxil1. Gastroenterology 2003, 125:107-116.

8. Sumi H, Yokosuka O, Seki N, Arai M, Imazeki F, Kurihara T, Kanda T, Fukai K, Kato $M$, Saisho $H$ : Influence of hepatitis $B$ virus genotypes on the progression of chronic type B liver disease. Hepatology 2003, 37:19-26.

9. Orito E, Mizokami M, Sakugawa H, Michitaka K, Ishikawa K, Ichida T, et al: A case-control study for clinical and molecular biological differences between hepatitis B viruses of genotypes B and C. Japan HBV Genotype Research Group. Hepatology 2001, 33:218-223.

10. Khichi GQK, Channar MS: Prevalence of hepatitis B carriers among children in Bahawalpur urban slums. Pak J Med Sci 2000, 16:238-241.

11. Khattak MF, Salamat N, Bhatti FA, Qureshi TZ: Seroprevalence of hepatitis B, C and HIV in blood donors in northern Pakistan. J Pak Med Assoc 2002, 52:398-402.

12. Akhtar S, Younus M, Adil S, Hassan F, Jafri SH: Epidemiologic study of chronic hepatitis $B$ virus infection in male volunteer blood donors in Karachi, Pakistan. BMC Gastroenterol 2005, 5:26.

13. Abbas Z, Muzaffar R, Siddiqui A, Naqvi SAA, Rizvi SAH: Genetic variability in the precore and core promoter regions of hepatitis $B$ virus strains in Karachi. BMC Gastroenterol 2006, 6:20

14. Gilroy RK, Mukherjee S: Hepatitis A. Kanas Med Centre 2008

15. Cammack N, Rouse P, Marr CL, Reid PJ, Boehme RE, Coates JA, Penn CR, Cameron JM: Cellular metabolism of (-) enantiomeric 2'-deoxy-3'thiacytidine. Biochem Pharmacol 1992, 43:2059-2064.

16. Dienstag JL, Schiff ER, Wright TL, Perrillo RP, Hann HW, Goodman Z, et al: Lamivudine as initial treatment for chronic hepatitis B in the United States. N Engl J Med 1999, 341:1256-1263.

17. Lai CL, Chine RW, Leung NWY, Chang TT, Guan R, Tai Dl, et al: A one year trial of lamivudine for chronic hepatitis B. N Engl J Med 1998, 339:61-68.

18. Yuen MF, Fong DY, Wong DK, Yuen JC, Fung J, Lai CL: Hepatitis B virus DNA levels at week 4 of lamivudine treatment predict the 5-year ideal response. Hepatology 2007, 46:1695-1703.

19. Qureshi H, Arif A, Alam E: Treatment of HBV and HDV co-infection using lamivudine. J Ayub Med Coll Abbottabad 2009, 21:1-3.

20. Zuberi BF, Afsar S, Quraishy MS: Triple Hepatitis: Frequency and Treatment Outcome of co/super-Infection of Hepatitis C and D Among Patients of Hepatitis B. J Coll Physicians Surg Pak 2008, 18:404-407.

21. Khokhar N, Gill ML, Alam AY: Treatment of chronic Hepatitis B with Lamivudine. J Coll Physicians Surg Pak 2005, 15:78-80.

22. Buster $E H C J$, Janssen $H L A$ : Antiviral treatment for chronic hepatitis B virus infection-immune modulation or viral suppression? The Journal of Medicine 2006, 64:175-185.

23. Lok AS, Lai CL, Leung N, Yao GB, Cui ZY, Schiff ER, et al: Long-term safety of lamivudine treatment in patients with chronic hepatitis $B$. Gastroenterology 2003, 125:1714-1722. 
24. Pawlotsky JM, Dusheiko G, Hatzakis A, Lau D, Lau G, Liang TJ, et al: Virologic monitoring of hepatitis B virus therapy in clinical trials and practice: recommendations for a standardized approach. Gastroenterology 2008, 134:405-415

25. Sonneveld MJ, Janssen HLA: Pros and cons of peginterferon versus nucleos(t)ide analogues for treatment of chronic hepatitis B. Curr Hepatitis Rep 2010, 9:91-98.

26. Chang T, Gish RG, de-Man R, Gadano A, Sollano J, Chao Y, et al: A Comparison of Entecavir and Lamivudine for $\mathrm{HBeAg}$-Positive Chronic Hepatitis B. N Engl J Med 2006, 354:1001-10

27. Craxi A, Cooksley WG: Pegylated interferons for chronic hepatitis B. Antiviral Res 2003, 60:87-89.

28. Chang T, Suh DJ: Current approaches for treating chronic hepatitis B: when to start, what to start with, and when to stop. Hepatol Int 2008, 2 S19-S27.

29. Lau JYN, Bain VG, Naomov NV, Smith HM, Alexander GJ, Williams R: Effect of interferon-a on hepatits $B$ viral antigen expression in primary hepatocyte culture. Hepatology 1991, 14:9759.

30. Guan R: Interferon monotherapy in chronic hepatitis B. J Gastroenterol Hepatol 2000, 15:34-40.

31. Naeem MA, Khan I, Waris J, Usman M: Efficacy of Interferon therapy in patients of chronic hepatitis B viral infection treated at MH Rawalpindi. Professional Med J 2008, 15:380-386.

32. Zuberi BF, Quraishy MS, Afsar S, Akhtar N, Kumar A, Dodani SK: Treatment outcome in patients of hepatitis B with hepatitis D: Experience of 4 years at a tertiary care centre in Pakistan. J Coll Physicians Surg Pak 2007, 17:320-322.

33. Okushin H, Ohnishi T, Morii K, Uesaka K, Yuasa S: Short-term intravenous interferon therapy for chronic hepatitis B. World J Gastroenterol 2008, 14:3038-3043

34. Cooksley WG, Piratvisuth T, Lee SD, Mahachai V, Chao YC, Tanwandee T, Chutaputti A, Chang WY, Zahm FE, Pluck N: Peginterferon alpha-2a (40 $\mathrm{kDa})$ : an advance in the treatment of hepatitis $B$ e antigen-positive chronic hepatitis B. J Viral Hepat 2003, 10:298-305.

35. Okamoto H, Tsuda F, Sakugawa H, Sastrosoewinjo Rl, Imai M, Miyakawa Y, Mayumi M: Typing hepatitis B virus by homology in nucleotide sequence: comparison of surface antigen subtypes. J Gen Virol 1988, 69:2575-2583.

36. Huy $T, \operatorname{Ngoc} T$, Abe K: New complex recombinant genotype of hepatitis $B$ virus identified in Vietnam. J Virol 2008, 82:5657-5663.

37. Yu H, Yuan Q, Ge SX, Wang HY, Zhang YL, Chen QR, Zhang J, Chen PJ, Xia NS: Molecular and phylogenetic analyses suggest an additional. Hepatitis B virus genotype "I". PLoS One 2010, 5:9297.

38. Awan Z, Idrees M, Amin I, et al: Pattern and Molecular Epidemiology of Hepatitis B virus genotypes circulating in Pakistan. Infect Genet Evol 2010, 10:1242-1246.

39. Ahmed CS, Wang ZH, Bin Z, Chen JJ, Kamal M, Hou JL: Hepatitis B virus genotypes, subgenotypes, precore, and basal core promoter mutations in the two largest provinces of Pakistan. J Gastroenterol Hepatol 2009, 24:569-73

40. Baig S, Siddiqui A, Chakravarty R, Moatter T: Hepatitis B virus subgenotypes D1 and D3 are prevalent in Pakistan. BMC Research Notes 2009, 2:1.

41. Noorali S, Hakim ST, McLean D, Kazmi SU, Bagasra O: Prevalence of Hepatitis B virus genotype D in females in Karachi, Pakistan. J Infect Developing Countries 2008, 2:373-378.

42. Hakim ST, Kazmi SU, Bagasra O: Seroprevalence of hepatitis B and C genotypes among yung apparently healthy females of Karachi-Pakistan. Libyan J Med 2008, 3:66-70, AOP: 071123.

43. Alam MM, Zaidi SZ, Shaukat S, Sharif S, Angez M, Naeem A, et al: Common Genotypes of Hepatitis B virus prevalent in Injecting drug abusers (addicts) of North West Frontier Province of Pakistan. Virology J 2007, 4:63.

44. Baig S, Siddiqui AA, Ahmed W, Qureshi H, Arif A: The association of complex liver disorders with HBV genotypes prevalent in Pakistan. Virology J 2007, 4:128.

45. Kao JH, Wu NH, Chen PJ, Lai MY, Chen DS: Hepatitis B genotypes and the response to interferon therapy. J Hepatol 2000, 33:998-1002.

46. Wai CT, Chu CJ, Hussain M, Lok AS: HBV genotype B is associated with better response to interferon therapy in $\mathrm{HBeAg}$-positive chronic hepatitis than genotype C. Hepatology 2002, 36:1425-30.
47. Janssen HLA, Senturk H, Zeuzem S, Akarka U, Cakalluglu Y, Simon K, et al: Peginterferon alfa $2 \mathrm{~b}$ and lamivudine combination therapy compared withpeginterferon alfa $2 \mathrm{~b}$ for chronic $\mathrm{HBeAg}$ positive hepatitis $\mathrm{B}$ : randomized controlled trial in 307 patients. Hepatology 2003, 38:1323.

48. Erhardt A, Gobel T, Ludwig A: Response to antiviral treatment in patients infected with hepatitis B virus genotypes E-H. J Med Virol 2009, 81:1716-1720.

doi:10.1186/1743-422X-8-20

Cite this article as: Ali et al:: An overview of treatment response rates to various anti-viral drugs in Pakistani Hepatitis B Virus infected patients. Virology Journal 2011 8:20.

\section{Submit your next manuscript to BioMed Central and take full advantage of:}

- Convenient online submission

- Thorough peer review

- No space constraints or color figure charges

- Immediate publication on acceptance

- Inclusion in PubMed, CAS, Scopus and Google Scholar

- Research which is freely available for redistribution

Submit your manuscript at www.biomedcentral.com/submit
C Biomed Central 